\title{
FREE AND ESTERIFIED CHOLESTEROL CONCENTRATIONS IN THE HAMSTER OVARY DURING THE OESTROUS CYCLE, PREGNANCY AND LACTATION
}

\author{
D. G. HOFFMAN* AND A. B. FAJER \\ Department of Physiology, University of Maryland School of Medicine, \\ Baltimore, Maryland 21201, U.S.A. \\ (Received 18th Fanuary 1972)
}

\begin{abstract}
Summary. Esterified and non-esterified (free) cholesterol concentrations were determined in the hamster ovary and isolated corpora lutea during the oestrous cycle, pregnancy and lactation. A significant decrease was observed in the esterified fraction between pro-oestrus and oestrus. The administration of phenobarbital at pro-oestrus prevented ovulation and the fall in the concentration of cholesterol esters. Luteal sterols, in cycling animals, expressed as $\mathrm{mg} / 100 \mathrm{mg}$ ovary were 16.3 to $19.0 \%$ and 4.3 to $7.5 \%$ of the total ovarian free and esterified cholesterol, respectively.

During pregnancy, concentrations of esterified cholesterol were lower than those found during the cycle. Of the total ovarian cholesterol, $38.7 \%$ of the free and $10.3 \%$ of the esterified fractions were found in the corpora lutea.

During both the oestrous cycle and pregnancy, a larger proportion of cholesterol was found in the interstitial cells and follicular elements rather than in the corpora lutea. This finding is supported by the high concentrations observed during lactation, when no corpora lutea are formed.
\end{abstract}

\section{INTRODUGTION}

Quantitative studies on the ovarian hormones or hormonal precursors in the hamster are relatively scarce. Progesterone plasma concentration has been studied by Lukazewska \& Greenwald (1970) and Leavitt, Kline \& Blaha (1970). Ovarian venous blood concentrations of progesterone were reported by Hoffman \& Fajer (1970). Fajer (1971) and Fajer \& Hoffman (1971) described a high pregnenolone content in the ovarian venous blood of lactating hamsters as well as the presence of pregnanolone, $5 \alpha$ - and $5 \beta$-pregnanedione and small amounts of progesterone. In addition, Orsini \& Schwartz (1966) have reported on levels of $\mathrm{LH}$ found in the pituitary during the oestrous cycle,

* Present address: Department of Obstetrics and Gynecology, Yale University Medical School, New Haven, Connecticut 06510. 
while Goldman \& Porter (1970) have studied serum LH levels in intact and castrated hamsters. Ovarian cholesterol depletion has been demonstrated by Claesson, Diczfalusy, Hillarp \& Holberg (1948) in the rabbit ovary and Beyler \& Szego (1954) have reported a diminution of cholesterol in the rat ovary during the oestrous cycle. At present, there are no data concerning the distribution of precursor sterols in the hamster ovary or the relationship of these sterols to gonadotrophin stimulation and steroid secretion.

The purpose of this report is to describe ovarian cholesterol levels during different stages of the reproductive cycle (e.g. the oestrous cycle, pregnancy and lactation) and attempt to correlate them with the secretion of gonadotrophic and steroid hormones as reported in the literature.

\section{MATERIALS AND METHODS}

\section{Animals}

Cycling hamsters, weighing 100 to $150 \mathrm{~g}$, were supplied at approximately 60 days of age and allowed to acclimatize to the animal colony lighting conditions for 1 to 2 weeks before use. Two regular oestrous cycles were observed before any animal was included in an experimental group, and the morning of the discharge of oestrus was designated 'Day 2' of the cycle (Orsini, 1961). Females experiencing their first pregnancy were obtained on Day 10 of gestation and were killed on Day 12 or allowed to litter and used during lactation. All animals had free access to water and Wayne Lab-Blox feed, and were housed in polypropylene cages in a constant-temperature room kept on a $12 \mathrm{hr}$ light/12 hr dark schedule.

\section{Preparation of ovarian tissue}

Animals were killed by decapitation on the selected days of the oestrous cycle, pregnancy or lactation. Ovaries and some adherent adipose tissue were removed immediately and placed in ice-cold saline. The ovaries were dissected from the surrounding fat at low magnification, blotted on filter paper, and weighed to the nearest $0.2 \mathrm{mg}$ on a torsion balance. The tissue was stored in glass vials at $-20^{\circ} \mathrm{C}$ until ready for use ( 2 to 3 days).

\section{Blockade of ovulation}

Ovulation was blocked in cycling females by the subcutaneous injection of sodium phenobarbital U.S.P. (Merck and Co., Inc.), $80 \mathrm{mg} / \mathrm{kg}$ on the day of pro-oestrus, $6 \mathrm{hr}$ after the start of the light cycle. The occurrence of ovulation was checked by examining the Fallopian tubes for tubal ova at $\times 100$ magnification, on the morning of oestrus. Only those animals with no tubal ova were used.

\section{Determination of cholesterol and cholesteryl esters}

Two ovaries from each animal constituted material for an individual determination. Ovarian tissue was homogenized, and the lipids were extracted with acetone :ethanol according to Glick (1961). The extraction mixture was centrifuged at $2700 \mathrm{rev} / \mathrm{min}$ and the supernatant removed and evaporated under nitrogen at $40^{\circ} \mathrm{C}$. 
Cholesterol and cholesteryl esters were separated by thin-layer chromatography in petroleum ether: ethyl ether:acetic acid (90:10:1) according to the method described by Malins \& Mangold (1960), utilizing authentic cholesterol, cholesteryl oleate, and cholesteryl acetate standards. The free cholesterol was subsequently acetylated and rechromatographed. Cholesteryl esters and cholesteryl acetate were determined by a variation of the Cavanaugh and Glick adaptation of the Sperry and Schoenheimer method for cholesterol and its esters (Glick, 1961). Samples were read at $620 \mathrm{~m} \mu$ against a reagent blank in a Hitachi-Perkin Elmer Model 139 UV-VIS Spectrophotometer. Similar samples, but containing about $2000 \mathrm{ct} / \mathrm{min}$ of $\left[4-{ }^{14} \mathrm{C}\right]$ cholesterol and $\left[1-{ }^{14} \mathrm{C}\right]$ cholesteryl palmitate (New England Nuclear Corp.), were run simultaneously and used for the estimation of procedural losses. Radioactivity was assayed in toluene (50 mg/litre POPOP and $4 \mathrm{~g} / \mathrm{litre}$ PPO) using a liquid scintillation spectrometer with a $50 \%$ efficiency for ${ }^{14} \mathrm{C}$. All samples were subsequently adjusted to $100 \%$ recovery and results expressed as $\mathrm{mg} / 100 \mathrm{mg}$ tissue. Statistical analysis of the data was performed utilizing either the Duncan Multiple Range test or the Student's $t$ test (Bliss, 1967; Snedecor \& Cochran, 1967).

\section{RESULTS}

\section{The oestrous cycle}

At 10.00 hours pro-oestrus (Day 1), the mean cholesteryl ester concentration was $1.75 \mathrm{mg} / 100 \mathrm{mg}$ tissue. This value corresponds to the highest level observed during the cycle. By 10.00 hours oestrus (Day 2), the ester concentration had fallen significantly to $0.94 \mathrm{mg} / 100 \mathrm{mg}$ tissue from peak pro-oestrous levels $(P<0.01)$. On the 1st day of dioestrus (Day 3), the mean ester concentration rose to $1.39 \mathrm{mg} / 100 \mathrm{mg}$ tissue which was not significantly different from values observed on Day 4.

Free cholesterol levels were also depressed on the morning of oestrus, but the relative variation in the free fraction was not nearly as great as in the case of the esters. As can be seen in Text-fig. 1, the unesterified cholesterol concentration during the oestrous cycle was approximately one-third that of the esters, with the esterified: free $(\mathrm{E}: \mathrm{F})$ ratio ranging from 2.8 at oestrus to 4.2 at pro-oestrus. The concentration of free cholesterol at oestrus was significantly different from Days 1, 3 and 4 of the cycle but no statistical difference could be demonstrated between these days.

A total of twenty-eight animals was killed at 4-hr intervals during the 24-hr period between 10.00 hours pro-oestrus and 10.00 hours oestrus in order to follow the temporal drop in the cholesterol stores. The relative changes in both of these fractions can be seen in Table 1. Before 18.00 hours, there was no significant change in the ester concentration when examined by two-variable linear regression analysis. However, between 18.00 and 22.00 hours, a significant drop occurred which reached its lowest values between 02.00 and 10.00 hours oestrus (Text-fig. 1). Free cholesterol values did not exhibit significant changes until after 22.00 hours pro-oestrus, reaching the lowest levels between 02.00 and 10.00 hours oestrus.

When ovulation was blocked by the administration of $80 \mathrm{mg} / \mathrm{kg}$ sodium 


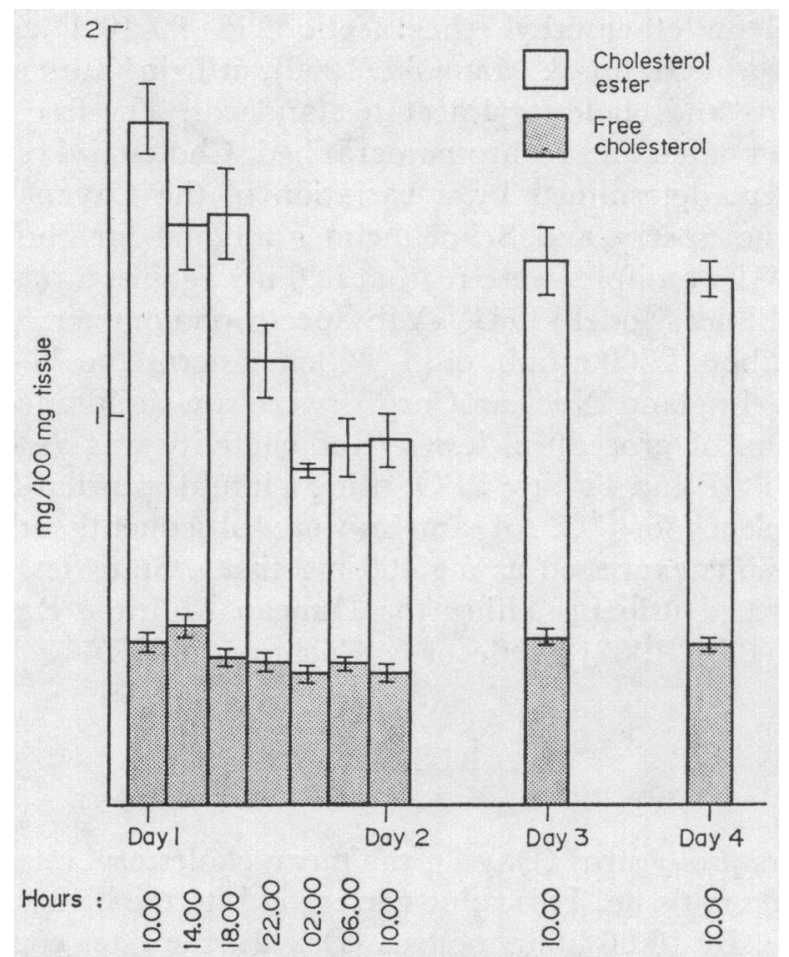

TEXT-Frg. 1. Ovarian free and esterified cholesterol concentrations during the oestrous cycle of the hamster. Vertical bars give S.E. of means.

Table 1. Ovarian free and esterified cholesterol concentrations in hamster ovary during the oestrous cycle and Day 12 of pregnancy

\begin{tabular}{|c|c|c|c|c|}
\hline Day of cycle & $\begin{array}{l}\text { Cholesteryl esters } \\
\text { (mg/100 mg ovary } \\
\pm \text { S.E.M. })\end{array}$ & $\begin{array}{c}\text { Free cholesterol } \\
\text { (mg/100 mg ovary } \\
\pm \text { S.E.M.) }\end{array}$ & $\begin{array}{l}\text { Ovarian weight } \\
(m g \pm S . E . M .)\end{array}$ & $\begin{array}{c}\text { Esterified: free } \\
(E: F) \text { ratio }\end{array}$ \\
\hline $\begin{array}{l}\text { Pro-oestrus: Day } 1 \\
10.00 \text { hours } \\
14.00 \text { hours } \\
18.00 \text { hours } \\
22.00 \text { hours }\end{array}$ & $\begin{array}{l}1 \cdot 75 \pm 0.09(13)^{*} \dagger \\
1.49 \pm 0.11 \\
1.52 \pm 0 \cdot 12 \\
1 \cdot 14 \pm 0.10\end{array}$ & $\begin{array}{ll}0.42 \pm 0.02 & (13) * * \\
0.46 \pm 0.03 & (7) \\
0.38 \pm 0.02 & (8) \\
0.37 \pm 0.03 & (6)\end{array}$ & $\begin{array}{l}22 \cdot 6 \pm 0.8 \\
21.9 \pm 1 \cdot 1 \\
24.4 \pm 0.7 \\
22 \cdot 5 \pm 1 \cdot 1\end{array}$ & $\begin{array}{l}4 \cdot 2 \\
3 \cdot 2 \\
4 \cdot 0 \\
3 \cdot 1\end{array}$ \\
\hline $\begin{array}{c}\text { Oestrus : Day } 2 \\
02.00 \text { hours } \\
06.00 \text { hours } \\
10.00 \text { hours }\end{array}$ & $\begin{array}{ll}0.86 \pm 0.02 & (3) \\
0.92 \pm 0.08 & (4) \\
0.94 \pm 0.07 & (9) *\end{array}$ & $\begin{array}{ll}0.33 \pm 0.01 & (3) \\
0.36 \pm 0.01 & (4) \\
0.34 \pm 0.02 & (9) * *\end{array}$ & $\begin{array}{l}23.0 \pm 1.3 \\
23.1 \pm 0.9 \\
25.3 \pm 1.2\end{array}$ & $\begin{array}{l}2 \cdot 6 \\
2 \cdot 6 \\
2 \cdot 8\end{array}$ \\
\hline $\begin{array}{l}\text { Dioestrus } 1 \text { : Day } 3 \\
10.00 \text { hours }\end{array}$ & $1.39 \pm 0.09(10)$ & $0.43 \pm 0.01(10)$ & $25 \cdot 8 \pm 0 \cdot 7$ & $3 \cdot 2$ \\
\hline $\begin{array}{l}\text { Dioestrus 2: Day } 4 \\
10.00 \text { hours }\end{array}$ & $1.34 \pm 0.04(10)$ & $0.42 \pm 0.01(10)$ & $25 \cdot 6 \pm 1 \cdot 1$ & $3 \cdot 2$ \\
\hline Pregnancy: Day 12 & $0.39 \pm 0.03$ & $0.31 \pm 0.01$ & $37 \cdot 6 \pm 1 \cdot 7$ & $1 \cdot 3$ \\
\hline
\end{tabular}


phenobarbital at 13.00 hours pro-oestrus, the drastic ester depletion was not observed at 10.00 hours oestrus. As reported in Table 2, the cholesteryl ester concentration on Day 2 was significantly higher in oestrous animals treated with phenobarbital than in saline-injected controls $(P<0.001)$. Ester levels in the phenobarbital-treated group were not significantly different from the mean ester concentrations observed on Days 3 and 4 of the cycle. Free cholesterol levels in the phenobarbital-treated group were not significantly different from those of controls, but did differ $(P<0.025)$ from the values for normal uninjected oestrous females at 10.00 hours.

\section{Day 12 of pregnancy}

On Day 12 of gestation, the E:F ratio was approximately 1.3 in the whole ovary, compared to $2 \cdot 6$ to $4 \cdot 2$ for the whole ovary during the oestrous cycle.

Table 2. Ovarian free and esterified cholesterol concentrations in hamsters after ovulatory blockade with phenobarbital

\begin{tabular}{|c|c|c|c|}
\hline Group & $\begin{array}{l}\text { Cholesteryl esters } \\
\text { (mg/100 mg whole } \\
\text { ovary } \pm \text { S.E.M. })\end{array}$ & $\begin{array}{l}\text { Free cholesterol } \\
\text { (mg/100 mg whole } \\
\text { ovary } \pm \text { S.E.M. })\end{array}$ & $\begin{array}{l}\text { Ovarian weight } \\
(m g \pm S . E . M .)\end{array}$ \\
\hline $\begin{array}{l}\text { Phenobarbital-treated } \\
\text { Gontrols } \\
\text { Oestrus ( } 10.00 \text { hours) }\end{array}$ & $\begin{array}{l}1.35 \pm 0.07(10)^{*} \dagger \\
0.98 \pm 0.07(10)^{*} \\
0.94 \pm 0.07 \quad(9)\end{array}$ & $\begin{array}{l}0.39 \pm 0.01(10) * * * \\
0.35 \pm 0.02(10) \\
0.34 \pm 0.02(9) * *\end{array}$ & $\begin{array}{l}19 \cdot 4 \pm 0 \cdot 8 \\
26 \cdot 1 \pm 0 \cdot 9 \\
25 \cdot 3 \pm 1 \cdot 2\end{array}$ \\
\hline
\end{tabular}

$* P<0.001 ; \quad * * P<0.025$.

$\uparrow$ Number of determinations.

Table 3. Free and esterified cholesterol concentrations in isolated hamster corpora lutea during the oestrous cycle and Day 12 of pregnancy

\begin{tabular}{|c|c|c|c|c|c|c|}
\hline & \multicolumn{3}{|c|}{$\mathrm{mg} / 100 \mathrm{mg}$ luteal tissue } & \multicolumn{3}{|c|}{$m g / 100 m g$ ovary } \\
\hline & $\begin{array}{l}\text { Cycle } \\
\text { Day } 3\end{array}$ & $\begin{array}{l}\text { Cycle } \\
\text { Day } 4\end{array}$ & $\begin{array}{c}\text { Pregnancy } \\
\text { Day } 12\end{array}$ & $\begin{array}{l}\text { Cycle } \\
\text { Day } 3\end{array}$ & $\begin{array}{l}\text { Cycle } \\
\text { Day } 4\end{array}$ & $\begin{array}{c}\text { Pregnancy } \\
\text { Day } 12\end{array}$ \\
\hline Cholesteryl esters & $\begin{array}{r}0.39(6)^{*} \\
\pm 0.03\end{array}$ & $\begin{array}{r}0.62(6) \\
\pm 0.07\end{array}$ & $\begin{aligned} & 0.10(4) \\
\pm & 0.01\end{aligned}$ & 0.06 & $0 \cdot 10$ & 0.04 \\
\hline Free cholesterol & $\begin{array}{r}0.42 \\
\pm 0.02\end{array}$ & $\begin{array}{r}0.46 \\
\pm 0.04\end{array}$ & $\begin{array}{r}0.03 \\
\pm 0.03\end{array}$ & 0.07 & 0.08 & $0 \cdot 12$ \\
\hline
\end{tabular}

* Number of determinations.

During pregnancy, the absolute ester levels were substantially lower than during the cycle (25 to $33.3 \%$ of cyclic values). The mean free cholesterol concentration on Day 12 was lower than the free levels observed on Days 1, 3 and 4 of the cycle, but did not significantly differ from those seen on Day 2.

\section{Isolated corpora lutea}

The concentration of cholesteryl esters underwent a $59 \%$ increase in luteal tissue between Days 3 and 4, rising from $0.39 \mathrm{mg} / 100 \mathrm{mg}$ luteal tissue to 0.62 $\mathrm{mg} / 100 \mathrm{mg}$ luteal tissue. However, the luteal-free cholesterol exhibited little difference in concentration between Days 3 and 4, with mean values of 0.42 
and $0.46 \mathrm{mg} / 100 \mathrm{mg}$ luteal tissue, respectively. The sterol concentration in isolated corpora lutea on Day 12 of pregnancy was quite low and the E:F ratio favoured the free levels $(E: F=0.33$ ), as illustrated in Table 3 .

To assess the contribution of the corpus luteum to cholesterol levels in the whole ovary, luteal sterol concentrations in $\mathrm{mg} / 100 \mathrm{mg}$ luteal tissue were calculated in $\mathrm{mg} / 100 \mathrm{mg}$ whole ovary by multiplying the luteal sterol concentration by the percentage weight of the corpora lutea per two ovaries. Thus, when luteal sterol levels were expressed in terms of the whole ovary, the corpora lutea were found to contribute 16.3 to $19.0 \%$ of the whole-ovary free cholesterol

Table 4. Percentage contribution of luteal tissue to whole ovary cholesterol concentrations in hamsters

\begin{tabular}{|c|c|c|c|}
\hline & $\begin{array}{l}\text { Cycle } \\
\text { Day } 3\end{array}$ & $\begin{array}{l}\text { Cycle } \\
\text { Day } 4\end{array}$ & $\begin{array}{c}\text { Pregnancy } \\
\text { Day } 12\end{array}$ \\
\hline $\begin{array}{l}\text { Cholesteryl esters } \\
\text { Free cholesterol }\end{array}$ & $\begin{array}{r}4 \cdot 3 \\
16 \cdot 3\end{array}$ & $\begin{array}{r}7.5 \\
19 \cdot 0\end{array}$ & $\begin{array}{l}10 \cdot 3 \\
38 \cdot 7\end{array}$ \\
\hline
\end{tabular}

Table 5. Contribution of corpora lutea to whole ovarian weight in hamsters

\begin{tabular}{|c|c|c|c|}
\hline & $\begin{array}{l}\text { Cycle } \\
\text { Day } 3\end{array}$ & $\begin{array}{l}\text { Cycle } \\
\text { Day } 4\end{array}$ & $\begin{array}{c}\text { Pregnancy } \\
\text { Day } 12\end{array}$ \\
\hline $\begin{array}{l}\text { Ovarian weight } \\
\text { (mg } \pm \text { S.E.M.) }\end{array}$ & $\underset{(6)}{28 \cdot 3 \pm 1 \cdot 3}$ & $23 \cdot 2 \pm 0 \cdot 7$ & $38 \cdot 4+1 \cdot 2$ \\
\hline $\begin{array}{l}\text { Corpus luteum weight } \\
(\mathrm{mg} \pm \text { S.E.M.) }\end{array}$ & $0.33 \pm 0.001$ & $0.30 \pm 0.001$ & $1 \cdot 18 \pm 0.04$ \\
\hline $\begin{array}{l}\text { Mean number of corpora lutea } \\
\text { (two ovaries) }\end{array}$ & 14 & 13 & 13 \\
\hline $\begin{array}{l}\text { Weight of corpora lutea as } \% \text { of } \\
\text { the ovarian weight }\end{array}$ & $16 \cdot 3$ & $16 \cdot 8$ & $39 \cdot 9$ \\
\hline
\end{tabular}

* Number of animals.

and 4.3 to $7.5 \%$ of the whole-ovary esterified cholesterol on Days 3 and 4 of the cycle. During the 12th day of gestation, the luteal tissue contributes to $38.7 \%$ of the whole-ovary free cholesterol and to $10.3 \%$ of the whole-ovary esterified cholesterol (Table 4). When individual corpora lutea from Days 3 and 4 of the cycle (dioestrus) and Day 12 of gestation were weighed, they were found to constitute, respectively, 16.3 to $16.8 \%$ and $39.9 \%$ of the ovarian weight (Table 5).

\section{Lactation}

During lactation, the esterified fraction reached the highest values for any of the reproductive states studied in this investigation. During the first days of lactation, cholesteryl ester concentrations were slightly higher than at prooestrus but reached peak concentrations of $2 \cdot 03 \pm 0 \cdot 14 \mathrm{mg} / 100 \mathrm{mg}$ tissue on the 8 th day. The concentrations of free cholesterol were always lower than those of 
the esterified fraction, with $E: F$ ratios ranging from 1.9 to 3.3 (Table 6). Concentrations of free cholesterol were high during the first 8 days. Their decline was more erratic than that of the esterified fraction. However, their values remained 1.3 to 2.2 times greater than during the oestrous cycle.

Table 6. Ovarian free and esterified cholesterol concentrations during lactation in the hamster

\begin{tabular}{|c|c|c|c|c|}
\hline $\begin{array}{l}\text { Day of } \\
\text { lactation }\end{array}$ & $\begin{array}{l}\text { Cholesteryl esters } \\
(m g / 100 \mathrm{mg} \text { ovary } \\
\pm \text { S.E.M.) }\end{array}$ & $\begin{array}{c}\text { Free cholesterol } \\
\text { (mg/100 mg ovary } \\
\pm S . E . M .)\end{array}$ & $\begin{array}{c}\text { Ovarian } \\
\text { weight } \\
\text { (mg } \pm \text { S.E.M. })\end{array}$ & $\begin{array}{l}E: F \\
\text { ratio }\end{array}$ \\
\hline $\begin{array}{c}2 \text { to } 3 \\
7 \\
8 \\
10 \\
11 \\
13 \\
15 \\
20\end{array}$ & $\begin{array}{l}1.77 \pm 0.12(6)^{*} \\
1.52 \pm 0.05(6) \\
2.03 \pm 0.14(4) \\
1.18 \pm 0.13(7) \\
1.36 \pm 0.18(5) \\
1 \cdot 18 \pm 0.08(7) \\
1.27 \pm 0.09(8) \\
1.04 \pm 0.06(6)\end{array}$ & $\begin{array}{l}0.91 \pm 0.06(6) \\
0.69 \pm 0.03(6) \\
0.87 \pm 0.03(4) \\
0.55 \pm 0.04(7) \\
0.72 \pm 0.03(5) \\
0.36 \pm 0.01(7) \\
0.65 \pm 0.03(8) \\
0.39 \pm 0.04(6)\end{array}$ & $\begin{array}{l}20.8 \pm 2.2 \\
29.2 \pm 1.8 \\
24.9 \pm 1.8 \\
32.6 \pm 2.0 \\
35.6 \pm 3.8 \\
33.8 \pm 1.6 \\
31.0 \pm 1.8 \\
36.5 \pm 1.2\end{array}$ & $\begin{array}{l}1 \cdot 9 \\
2 \cdot 2 \\
2 \cdot 3 \\
2 \cdot 2 \\
1.9 \\
3 \cdot 3 \\
2 \cdot 0 \\
2 \cdot 7\end{array}$ \\
\hline
\end{tabular}

* Number of determinations.

\section{DISGUSSION}

Our results show that depletion of cholesterol esters during the oestrous cycle is temporally related to pituitary and plasma gonadotrophin levels and progesterone secretion. The pro-oestrus drop in the esterified fraction begins after the pituitary concentrations of ovulating hormone have dropped (Greenwald, 1971) and after the plasma levels of LH have reached their highest values (Goldman \& Porter, 1970).

Since FSH has been shown to be involved in the ovulatory process (Goldman \& Mahesh, 1969) and shown to be synergistic with LH in causing ovulation in hypophysectomized hamsters (Greenwald, 1971), an effect of FSH on cholesterol in the interstitium cannot be ruled out. In the rat, such an effect could not be demonstrated by histochemical methods (Zarrow \& Clark, 1969).

The rôle of prolactin during the periovulatory period is unclear. Since the cyclic corpora lutea are described as non-functional, very little prolactin must be secreted, despite the dioestrus progesterone peak in the ovarian venous blood (Hoffman \& Fajer, 1970). The recovery of the ester fraction during dioestrus involves the interstitial tissue. This fact was shown histochemically (Guraya \& Greenwald, 1965) and substantiated by our results. During the oestrous cycle, the luteal contribution to the total ovarian weight was about $16 \%$ while the cholesteryl ester level in the corpus luteum was relatively low (Table 4). Thus, the rise in cholesterol in dioestrus cannot be attributed solely to the corpora lutea.

The effect of phenobarbital in suppressing the depletion of cholesteryl esters seems to be related to its effect on the ovulatory hormone(s). Phenobarbital suppresses ovulation in the hamster and this action can be overcome with LH, FSH or a combination of both gonadotrophins (Greenwald, 1971). 
During pregnancy, the concentration of the esters is $30 \%$ of that found during the cycle, while free cholesterol values are in the same range as those seen at oestrus. Beyler \& Szego (1954) found that the levels of esterified cholesterol in the residual rat ovary (corpora lutea removed) were elevated over those of the cycle, while the luteal ester values were depressed. In the hamster during the 12th day of pregnancy, the corpora lutea represent $39.9 \%$ of the ovarian weight, but contribute only $10 \%$ of the esterified cholesterol and $38.7 \%$ of the free cholesterol. During gestation, the luteal sterol values are higher than those found during the cycle, but the contribution of the luteal tissue has increased from dioestrus levels (Table 5). The drop in luteal cholesteryl esters from 0.62 $\mathrm{mg} \%$ on Day 4 of the cycle to $0.10 \mathrm{mg} \%$ during pregnancy is evident (Table 3 ). Thus, the low interstitial and luteal concentrations of esterified cholesterol are in opposition to the increase in the same fraction in the rat residual ovary. If the depletion of the esters is taken to be a sign of secretory activity, then the interstitial tissue of the hamster ovary is active during pregnancy. Blaha \& Leavitt (1970) have reported steroid dehydrogenase activity in the interstitium throughout gestation and Fajer (1971) and Fajer \& Hoffman (1971) have demonstrated the presence of pregnenolone and pregnandione in the ovarian venous blood of pregnant hamsters, presumably of interstitial origin.

The lactational ovary of the hamster is devoid of corpora lutea and the interstitial tissue is hypertrophied. The vaginal smear and uterine weight do not indicate secretion of oestrogens or progestins (Greenwald, 1965; D. C. Hoffman \& A. B. Fajer, unpublished observations), and the biological significance of the different steroids found in the ovarian venous blood remains to be established (Fajer, 1971).

The concentrations of esterified cholesterol are in the range of those found at pro-oestrus and the free cholesterol levels have an average value which is $64 \%$ above the 'oestrus' peaks. Thus, cholesterol storage is maximal during lactation (Table 6).

As for the rat luteal tissue (Everett, 1947) and for the rabbit interstitial tissue (Hilliard, Spies, Lucas \& Sawyer, 1968), this sterol storage may be related to a particular prolactin:LH ratio.

Our observations relate the drop in cholesteryl ester concentration with the observed pro-oestrus peak of progesterone in the ovarian venous blood (Hoffman \& Fajer, 1970) and in peripheral plasma (Lukazewska \& Greenwald, 1970 ), and give support to the proposed interstitial origin of this progesterone. The existence of an extraluteal source of progesterone is not surprising; in the rat, the adrenal secretes progesterone (Fajer, Holzbauer \& Newport, 1971).

The study of ovarian cholesterol points to a more major rôle for the interstitium in the hamster than has previously been described for a laboratory animal other than the rabbit (Hilliard et al., 1968).

\section{ACKNOWLEDGMENTS}

This work was partially supported by grants from the National Science Foundation (GB-26462) and the National Institutes of Health (USPHS GM-1075 and HD-00167). 


\section{REFERENCES}

Beyler, A. L. \& Szego, C. M. (1954) Correlation of ovarian cholesterol levels with changes in $\beta$ glucuronidase activity of reproductive tract during the estrous cycle and pregnancy. Endocrinology, $54,323$.

Blaha, G. C. \& Leavrrt, W. W. (1970) The distribution of ovarian $\Delta 5-3 \beta$-hydroxysteroid dehydrogenase activity in the golden hamster during the estrous cycle, pregnancy and lactation. Biol. Reprod. 3, 362.

Burss, C. I. (1967) Statistics in biology, Vol. I. McGraw-Hill, New York.

Clafesson, L., Digzfalusy, E., Hillarp, N. A. \& Holberg, B. (1948) The formation mechanism of oestrogenic hormones. III. Lipids of the pregnant rabbit ovary and their change at gonadotropic stimulation. Acta physiol. scand. 16, 183.

EVERETT, J. (1947) Hormonal factors responsible for deposition of cholesterol in the corpus luteum of the rat. Endocrinology, 41,364 .

FAJER, A. B. (1971) Loci of action of prolactin and luteinizing hormone in the hamster during lactation: the interstitial tissue. Recent Advances in Endocrinology. Excerpta Medica Int. Congress Series, 238, 176.

Fajer, A. B. \& Hoffman, D. C. (1971) Sterols and steroids in the ovary and ovarian blood of the hamster. Fedn Proc. Fedn Am. Socs exp. Biol. 30, 595.

Fajer, A. B., Holzbauer, M. \& NewPort, H. M. (1971) The contribution of the adrenal gland to the total amount of progesterone in the female rat. F. Physiol., Lond. 214, 115.

Gurck, D. (1961) Quantitative chemical techniques of histo and cytochemistry, Vol. II. Interscience Publishers, New York.

Goldman, B. D. \& MAHesh, V. B. (1969) A possible role of acute FSH-release in ovulation in the hamster as demonstrated by utilization of antibodies to LH and FSH. Endocrinology, 84, 236.

Goldman, G. S. \& Porter, J. C. (1970) Serum LH levels in intact and castrated golden hamsters. Endocrinology, 87, 676.

GReEnwald, G. S. (1965) Histologic transformation of the ovary of the lactating hamster. Endocrinology, 77, 641 .

Greenwald, G. S. (1971) Preovulatory changes in ovulating hormone in the cyclic hamster. Endocrinology, 88, 671 .

Guraya, S. S. \& Greenwald, G. S. (1965) A histochemical study of the hamster ovary. Am. F. Anat. 116, 257.

Hilliard, J., Spies, G., Lucas, L. \& Sawyer, C. H. (1968) Effect of prolactin on progestin release and cholesterol storage by rabbit ovarian interstitum. Endocrinology, 82, 122.

Hoffman, D. C. \& Fajer, A. B. (1970) Progesterone concentration in the ovarian venous blood of the hamster during the estrous cycle and pregnancy. Fedn Proc. Fedn Am. Socs exp. Biol. 29, 250.

LeavitT, W. W., Kline, D. L. \& Blaha, G. G. (1970) Plasma progesterone and cortisol levels in the hamster during the estrous cycle and pregnancy. Fedn Proc. Fedn Am. Socs exp. Biol. 25, 705.

Lukazewska, J. \& Greenwald, G. S. (1970) Progesterone levels in the cyclic and pregnant hamster. Endocrinology, 86, 1.

Malins, D. G. \& MANGOLd, H. K. (1960) Analysis of complex mixtures by thin layer chromatography and complementary methods. 7. Am. Oil Chem. Soc. 37, 576.

Orsini, M. W. (1961) The external vaginal phenomena characterizing the stages of estrous cycle, pregnancy, pseudopregnancy, lactation and the anestrous hamster (Mesocricetus auratus, Waterhouse). Proc. Anim. Care Panel, 11, 193.

Orsini, M. W. \& Schwartz, N. B. (1966) Pituitary LH content during the estrous cycle in female hamsters, comparison of male and acyclic females. Endocrinology, 78, 34.

Snedecor, G. W. \& Cochran, W. G. (1967) Statistical methods, 6th edn. Iowa State University Press. Iowa.

Zarrow, M; X. \& Clark, J. H. (1969) Gonadotropin regulation of ovarian cholesterol levels in the rat. Endocrinology, 84, 340. 